\title{
Peningkatan Daya Saing Internasional Krusial dalam Exit Strategi dari Program IMF
}

\author{
Sri Adiningsih
}

Based on Indonesian economy development lately, it could be said that fundamental macro economy stronger than before. This condition indicates that could be a basic for indonesia to exit from IMF program. Because of this, if this policy can be reached and the microeconomics can be structured, the IMF exit strategy will not shock Indonesian economy. So it is important to build competitive advantage especially how to increase export, infestation and decrease imported goods. Forlong term, this policy prepares the opportunity to create a vocation, so the unemployment problems can be solved.

emerintah pada akhirnya sudah menentukan pilihannya dalam exit dari program International Monetary Fund (IMF) pada akhir tahun 2003 ini. Keputusan penting tersebut yang sudah lama ditunggu pada akhirnya diputuskan oleh pemerintah. Kesulitan pemerintah dalam mengambil keputusan tersebut memang dapat dipahami, karena apa pun keputusannya tetap akan menimbulkan kontroversi dan juga akan banyak mempengaruhi masa depan ekonomi Indonesia. Apalagi memang ada berbagai wacana mengenai opsi yang sebaiknya dipilih oleh pemerintah dari berbagai kalangan, baik domestik maupun internasional.

Meskipun opsi sudah dipilih oleh pemerintah dalam rangka lulus dari program IMF, namun masih saja memunculkan silang pendapat. Namun demikian satu hal yang sudah pasti adalah bahwa akhir 2003, program IMF sudah selesai di Indonesia, sesuai dengan Tap MPR Nomor VI tahun 2002. Meski demikian Indonesia masih tetap menjadi anggota IMF, sehingga ada hak dan kewajiban yang juga harus kita penuhj sebagai anggota IMF. Hanya saja karena pilihan pemerintah adalah membayar kewajiban sesuai dengan tanggal jatuh temponya, maka akan ada Post Program Monitoring (PPM) yang dilakukan IMF karena Indonesia mempunyai hutang sekitar $300 \%$ dari quota untuk Indonesia. Sesuai dengan peraturan IMF terhadap anggotanya yang mempunyai hutang lebih dari $100 \%$ quota akan dikenakan PPM. Meskipun ada PPM kita tidak perlu khawatir karena monitoring hanya dilakukan 2 kali dalam setahun dan sifatnya tidak mengikat. Tidak seperti Letter of Intents (Lols).

Opsi yang diambil oleh pemerintah tersebut adalah pilihan yang paling konservatif bagi Indonesia. Melihat berbagai opsi lainnya adalah mengandung resiko yang besar bagi Indonesia (jika hal-hal yang diluar dugaan terjadi), atau masih dalam program IMF yang akan menabrak Tap MPR tersebut di atas. Padahal seperti kita ketahui bahwa Pemilu yaing berpotensi meningkatkan suhu sosial, politik dan keamanan 
akan digelar pada tahun 2004, dimana jika tidak dapat dijaga dengan baik berpotensi menggoncang perekonomian. Oleh karena itu pilihan yang konservatif tersebut adalah yang terbaik bagi Indonesia pada saat ini. Jika kondisi ekonomi membaik, cadangan devisa menguat, dan keuangan negara sudah aman lagi pasca Pemilu 2004. percepatan pembayaran masih dapat dikejar. Negara seperti Thailand dan Korea Selatan juga melakukan percepatan pembayaran ke IMF pada saat ekonominya sudah semakin kuat.

Meski pilihan yang baik sudah diambil, namun masa depan ekonomi Indonesia juga belum sepenuhnya aman. Berbagai masalah dan tantangan masih banyak yang menghadang. Oleh karena itu strategi yang baik timely pasca program IMF sangatlah menentukan keberhasilan Indonesia dalam mengawal kemajuan ekonominya ke depan. Apalagi ekonomi Indonesia sendiri sampai sekarang meskipun sudah membaik secara signifikan, namun juga belum berfungsi normal. Indonesia terjebak kedalam pertumbuhan ekonomi yang rendah ( $3 \% \mathrm{~s} / \mathrm{d} 4 \%)$ dalam dua tahun terakhir ini, dan mungkin tahun-tahun ke depan jika masalah struktural yang dihadapinya tidak dapat segera diatasi.

\section{Potret Ekonomi}

Potret ekonomi yang sudah semakin membaik dari Indonesia, khususnya pada sisi makro sayangnya belum didukung oleh perbaikan pada sisi mikro. Sehingga tidaklah mengherankan jika daya dorong pergerakan ekonomi menjadi sangat terbatas. Ekonomi yang selama inì lebih banyak didorong oleh pengeluaran konsumsi, khususnya dari pemerintah dan rumah tangga, tidak dapat diharapkan cukup kuat untuk mendorong laju pertumbuhan ekonomi. Meskipun mulai tahun 2003 sudah ada sedikit perbaikan pada laju pertumbuhan investasi yang tumbuh $6,40 \%$ pada kwartal 1 dan sebesar 4,87 pada kwartal 2. Namun demikian pada periode yang sama ekspor masih hanya tumbuh di bawah $1 \%$. Itu semua membuat kemampuan ekonomi untuk dapat tumbuh paling tidak $5 \%$, sehingga' dapat menciptakan cukup kesempatan kerja masih jauh dari harapan.

Pertumbuhan ekonomi yang rendah telah membuat tingkat pengangguran bertambah setiap tahun. Bahkan jumlah pengangguran terbuka sudah mencapai 9,1 juta jiwa yang merupakan 9,1 persen dari total angkatan kerja pada tahun 2002, meningkat dari tahun sebelumnya yang sebesar 8,0 juta jiwa atau 8,1 persen dari total angkatan kerja. Jumlah pengangguran diperkirakan sudah akan mencapai 10 juta orang pada akhir 2003, angka yang sudah amat mengkhawatirkan. Sementara itu jumlah penduduk miskin absolut masih sangat besar, menjadi 38,4 juta $(18,2 \%)$ dari jumlah penduduk, pada tahun 2002. Selain itu peringkat Indeks Pembangunan Manusia (Human Development Index, HDI) Indonesia menurun dari 102 pada tahun 2001 menjadi 110 pada tahun 2002. Itu semua memberikan potret yang masih suram bagi kehidupan bangsa ini secara keseluruhan. Dimana jika masalah mendasar tersebut tidak dapat segera diperbaiki berpotensi menyimpan bom waktu yang serius bagi Indonesia.

Meski dari sisi kehidupan masyarakat masih jauh dari harapan namun terjaganya kestabilan ekonomi makro dengan baik sangat membantu usaha revitalisasi ekonomi. Seperti kita ketahui bahwa kestabilan ekonomi makro tentu saja sangat penting dalam rangka merevitalisasi ekonomi, sebab dengan adanya kestabilan ekonomi makro maka usaha untuk 
mengatasi berbagai permasalahan ekonomi yang dapat muncul karena exit dari program IMF akan lebih mudah dilakukan. Dimana kestabilan rupiah yang dapat dilihat dari tingkat inflasi (dibawah $7 \%$ tahunan) dan kurs (sekitar Rp8500 tiap dolar AS) yang dapat lebih dikendalikan pada tingkat yang moderat, dan turunnya suku bunga (SBI 1 bulan di kisaran $8 \%$ ) akan memudahkan usaha-usaha mengamankan ekonomi indonesia pasca program IMF. Demikian juga defisit fiskal $(1,8 \%$ dari PDB pada tahun 2003) dan porsi hutang pada PDB (sekitar $70 \%$ dari PDB pada tahun 2003) yang semakin menurun akan memudahkan pemerintah mengelola anggarannya. Oleh karena itu dapat dikatakan bahwa Indonesia sudah siap untuk lulus dari program IMF.

Kelulusan Indonesia dari program IMF tidak akan banyak artinya jika perekonomian tidak dapat segera bangkit mengatasi masalah struktural yang kita hadapi. Modal dasar yang kita miliki mestinya digunakan untuk menjawab masalah dasar yang kita hadapi. Oleh karena itu kemajuan dari sisi makro tersebut mestinya digunakan sebagai basis dalam memperbaiki ekonomi mikro, sehingga kesempatan kerja yang mencupi dapat segera disediakan.

\section{Peningkatan Daya Saing Internasional}

Graduation dari program IMF tentu saja juga membawa berbagai konsekuensi bagi Indonesia. Beberapa manfaat yang dapat diperoleh dengan selesainya Program IMF adalah: kontroversi kehadiran IMF tidak ada lagi, Indonesia memiliki fleksibilitas dalam mendesain kebijakannya, dan memberikan perasaan bahwa Indonesia sudah tidak dalam krisis ekonomi. Dimana semuanya tentu saja akan dapat membantu mengatasi

- permasalahan-permasalahan yang dapat muncul, seperti halnya: Restrukturisasi utang luar negeri dalam Paris Club tidak dapat dilakukan (muncul masalah fiscal gap), cadangan devisa akan berkurang karena harus membayar hutang ke IMF, demikian juga ada potensi merosotnya kepercayaan pada perekonomian Indonesia (confidençe gap). Dimana berbagai tantangan dan permasalahan yang muncul tersebut tentu saja mempunyai potensi untuk menghambat proses revitalisasi ekonomi Indonesia. Oleh karena itu usaha untuk meminimisasi dampak negatif yang dapat muncul baik dari dampak selesainya program IMF ataupun bahkan Pemilu dan masalah bom akhir-akhir' ini perlu dilakukan dan diantisipasi dengan baik.

Kesempatan berakhirnya program IMF semestinya digunakan oleh pemerintah untuk mengatasi masalah besar yang dihadapi Indonesia, yaitu penurunan daya saing international Indonesia dari semua lembaga pemeringkat internasional. Rendahnya daya saing internasional, jelas akan mempersulit usaha untuk menyediakan kesempatan kerja bagi masyarakat karena semakin terdesaknya produk indonesia di pasar internasional ataupun domestik. Demikian juga daya tarik investasi akan semakin merosot, dapat dilihat dari peringkat Indonesia pada posisi nomor 3 paling rendah (nomor 138 dari 140 negara) di dunia berdasarkan hasil survey UNCTAD pada September 2003. 
IMD World Competitiveness 2003 (populasi $>20$ juta)

\begin{tabular}{|c|c|c|c|c|c|}
\hline \multirow[t]{2}{*}{ NEGARA } & \multicolumn{5}{|c|}{ TAHUN } \\
\hline & 1999 & 2000 & 2001 & 2002 & 2003 \\
\hline Argentina & 15 & 22 & 23 & 26 & 29 \\
\hline Auslialia & 3 & 3 & 3 & 3 & 2 \\
\hline Brazil & 17 & 15 & 16 & 15 & 21 \\
\hline Canada & 2 & 2 & 2 & 2 & 3 \\
\hline China Mainland & 11 & 11 & 12 & 12 & 12 \\
\hline Colombia & 23 & 23 & 21 & 20 & 16 \\
\hline France & 8 & 7 & 8 & 9 & 8 \\
\hline Gemmany & 4 & 4 & 4 & 4 & 5 \\
\hline India & 19 & 18 & 99 & 17 & 20 \\
\hline Indonesia & 25 & 24 & 24 & 25 & 28 \\
\hline Ilaly & $\overline{13}$ & 16 & 13 & 14 & 17 \\
\hline Jарап & 10 & 10 & 9 & 11 & 11 \\
\hline Korea & 21 & 12 & 19 & 10 & 15 \\
\hline Maharashtra (lndia) & 0 & 0 & 0 & 0 & 19 \\
\hline Malaysia & 9 & 9 & 10 & 6 & 4 \\
\hline Nexico & 14 & 14 & 15 & 19 & 24 \\
\hline Prilippines & 12 & 17 & 18 & 18. & 22 \\
\hline Poland & 20 & 19 & 25 & 22 & 27 \\
\hline Romania & 0 & 0 & 0 & 0 & 23 \\
\hline Russia & 26 & 26 & 22 & 21 & 26. \\
\hline Sao Paulo (Bravil) & 0 & 0 & 0 & 0 & 13 \\
\hline South Alfica & 22 & 20 & 17 & 16 & 18 \\
\hline Spain & 7 & $\mathrm{e}$ & 7 & 8 & 9 \\
\hline Taiwan. & 5 & 6 & 5 & 7 & 6 \\
\hline Thailand & 16 & 13 & 14 & 13 & 10 \\
\hline Tưkey & 18 & 21 & 2 & 23 & 25 \\
\hline Uniled Kirsodom & 6 & 5 & 6 & 5 & 7 \\
\hline USA & 1 & 1 & 1 & 1 & 1 \\
\hline Venezuela & 24 & 25 & 26 & 24 & 30 \\
\hline Zhejiang (Cina) & 0 & 0 & 0 & 0 & 14 \\
\hline
\end{tabular}

Sumber. IMD World Competitiveness Yearbook 2003

\section{Penutup}

Melihat perkembangan ekonomi akhirakhir ini, dapat dikatakan bahwa fundamental ekonomi secara makro semakin kuat yang dapat dilihat dari kestabilan ekonomi makro yang semakin membaik yang juga didukung oleh cadangan devisa yang meningkat dan defisit APBN yang semakin menurùn, serta porsi hutang terhadap PDB yang berkurang. Sehingga kondisi ekonomi dilihat dari sisi makro cukup kuat untuk basis Indonesia keluar dari program IMF. Dengan demikian selesainya program IMF meskipun dapat berimplikasi pada ekonomi makro, baik dilihat dari sisi anggaran maupun kestabilan ekonomi makro. Namun demikian secara umum jika kondisi ekonomi . makro yang sudah dicapai dapat dipertahankan, selesainya program IMF diperkirakan tidak akan banyak menggoncang perekonomian. Bahkan jika masalah ekonomi mikro dapat diperbaiki maka akan dapat memperkuat fundamental ekonomi makro kita. Oleh karena itu sangatlah penting bagi Indonesia untuk memperbaiki ekonomi mikro kita peningkatan daya saing internasional pada semua lini. Dengan perbaikan daya saing internasional akan dapat menjawab masalah besar ekonomi yang kita hadapi. Peningkatan daya saing internasional akan dapat meningkatkan ekspor, inves-tasi, dan juga menurunkan impor barang akhir (barang konsumsi). Dengan demikian akan dapat menggerakkan ekonomi dan menyediakan kesempatan kerja yang lebih besar. Sehingga masalah penggangguran yang menjadi momok pada saat ini dapat diatasi.

\section{Daftar Pustaka}

Adiningsih, Sri, "Ekonomi Indonesia Pasca Program IMF", PANGSA (Jurnal Ekonomi dan Pembangunan), Edisi 10/IX/2003

Masson, Paul R. dan Michael Mussa, "The . Role of the IMF: Financing and its Interactions with Adjustment and Surveillance", Pamphlet Series No. 50, International Monetary Fund, 1995

Statistik Ekonomi Keuangan Indonesia, berbagai edisi

Wond Competitiveness Yearbook 2003, IMD

World Investment Report 2003, UNCTAD 